\title{
The Effect On Mangrove Density With Sediment Rate in Coastal Pasar Banggi Of Rembang Regency
}

\author{
M. Arief Rahman Halim ${ }^{1, *}$, Yulizar Ihrami Rahmila ${ }^{1}$, Fuad Muhammad ${ }^{1}$ and Yuanita Safitri ${ }^{2}$ \\ Master Program of Environmental Science, School of Postgraduate Studies, Diponegoro University, Semarang - Indonesia
}

\begin{abstract}
The existence of mangrove ecosystems in coastal Pasar Banggi serves to protect the shoreline and wildlife habitat as fishing for spawning, nursery, and feeding ground. In addition, mangrove ecosystems can also grab sediments through the root system forming new land. The formation of the new land can eventually be utilized for mangrove growth media either naturally or through the planting activities to support the sustainability of mangrove ecosystems. The method used is vegetation analysis and sediment trap. The results showed that the dominant mangrove species in Coastal Pasar Banggi Rembang were Rhizopora apiculata. The results showed the average value of the highest sedimentation rate at station A 291,479 gr/cm2/day with the lowest average mangrove density of $57822 \mathrm{ind} / \mathrm{ha}$. The lowest average sedimentation rate at station B was 171,095 gr/cm2/day with the highest average mangrove density of $105311 \mathrm{ind} / \mathrm{ha}$, mean medium sedimentation rate at station $\mathrm{C}$ was $219,461 \mathrm{gr} / \mathrm{cm} 2 /$ day with average medium mangrove density of $888089 \mathrm{ind} / \mathrm{ha}$. This research is expected to be an information material about the rate of sedimentation which will be expected as a mangrove conservation management. Based on the results of the research, the relationship between mangrove density and sedimentation rate resulted in negative correlation (-1) meaning that the lower of mangrove density, the higher the sedimentation rate and the higher the mangrove density, the lower the sedimentation rate
\end{abstract}

Keywords: Mangrove Ecosystem, Sedimentation Rate, Coastal.

\section{INTRODUCTION}

Rembang Regency is a district located on the north coast of Java Island with an area of about $1,024 \mathrm{~km} 2$ with a coastline length of $63.5 \mathrm{~km} .35 \%$ of Rembang Regency is a coastal area of $355.95 \mathrm{~km} 2$. One of the coastal areas of mangrove forest located in the Pasar Banggi Village. Mangrove in coastal Rembang Regency is not a natural mangrove but the result of rehabilitation from all parties (government, community, and others), especially in Pasar Banggi area. Mangrove serves to keep the beach and ponds due to sea abrasion. Maulana et al [1] emphasizes that mangroves are an effective means of reducing disaster risks (abrasion) compared to coastal protection (physical) buildings, due to their limited life usage. According to Roza et al [2] mangrove is said to be one of the efforts to reduce the risk of abrasion due to mangrove roots capable of reducing energy, thus reducing the speed of water flow in the mangrove area. The slow flow rate of water can precipitate deposited particles or sedimentation. Studies on mangroves and sedimentation need to be done to determine the amount of sedimentation that occurs in the mangrove area and the relationship between the two, so that mangrove is said to be an effective effort in stabilizing the beach (shoreline) of abrasion.

\section{METODOLOGY}

\subsection{Time and Place}

The research was conducted in two stages in data collection, i.e. mangrove vegetation data and parameter data of physicochemical parameters on 19-21 November 2016, and data of sedimentation rate along with physicochemical parameter data from 26 November to 17 December 2016. Sediment sampling was taken as many 4 times with 7-day interval for 1 month.

\subsection{Material and Tools}

The research method used is sediment analysis method, mangrove vegetation analysis method, admiralty method, and statistical analysis method (correlation). Determination of the location of measurement and observation is done by using a tool of GPS (Global Positioning System) by purposive sampling that takes the sample of location representing the surrounding condition by taking into consideration and consider the condition of research location. Sampling location taking 9 points then divided into 3 stations for data collection of mangrove density. Each station is divided into two location points for sediment trap placement as well as sediment sampling (Fig 1).

\footnotetext{
*Corresponding author: Halimister69@gmail.com
} 


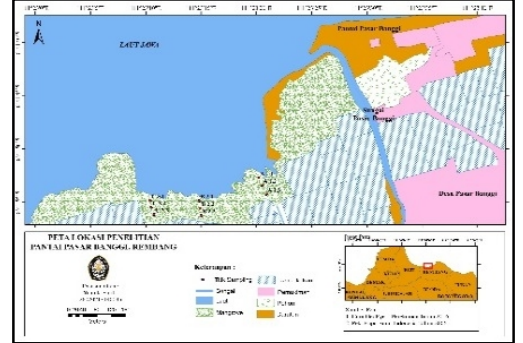

Fig 1. Map of Research Sites of Pantai Pasar Banggi, Rembang Regency

\section{RESULTS AND DISCUSSION}

\subsection{Result}

\subsubsection{Sedimentation Rate}

The result of calculation of sedimentation rate in Banggi mangrove area shows the largest sedimentation rate value at point A of 1.1 in the third sample is $568,656 \mathrm{gr} / \mathrm{cm}^{2} /$ day and the lowest sedimentation rate at point B 2.1 in the first sample is $53,361 \mathrm{gr} / \mathrm{cm}^{2} /$ day presented in Table 1 .

Table 1. Sedimentation rate values

\begin{tabular}{cccccc}
\hline \multicolumn{6}{c}{ Sedimentation Rate $\left(\mathrm{gr} / \mathrm{cm}^{2} / \mathrm{day}\right)$} \\
\hline $\begin{array}{c}\text { Po } \\
\text { int }\end{array}$ & $26 / 11 /$ & $03 / 12 /$ & $10 / 12 /$ & $17 / 12 /$ & Rata - \\
\hline A & 200,5 & 2016 & 2016 & 2106 & rata \\
$\begin{array}{c}1.1 \\
\text { A }\end{array}$ & 177,6 & 202,16 & 323,99 & 288,95 & 248,20 \\
$\begin{array}{c}1.2 \\
\text { B }\end{array}$ & 53,36 & 116,83 & 207,30 & 251,03 & 157,13 \\
2.1 & & & & & \\
B & 93,75 & 163,97 & 221,28 & 261,21 & 185,05 \\
2.2 & & & & & \\
C & 157,7 & 204,68 & 243,61 & 330,35 & 233,59 \\
3.1 & & & & & \\
C & 120,3 & 135,25 & 293,19 & 272,50 & 205,32 \\
3.2 & & & & & \\
\hline
\end{tabular}

\subsubsection{Sedimentation Debit}

Table 2 shows the highest sedimentation debit values at points A 1.1 and A 1.2 among other points. At the rate of sedimentation obtained at station A (point A 1.1 and A 1.2) is higher than other stations so it can be said that the sediment debit has a role or influence on the amount of sediment that is deposited and the sediment debit is directly proportional to the sedimentation rate.
Tabel 2. Sedimentation Debit Values

\begin{tabular}{cccccc}
\hline \multicolumn{6}{c}{ Debit (Q) Sedimentation $\left(\mathrm{cm}^{3} /\right.$ day) } \\
\hline Poi & $26 / 1$ & $03 / 1$ & $10 / 1$ & $17 / 1$ & Aver \\
nt & $1 / 20$ & $2 / 20$ & $2 / 20$ & $2 / 20$ & age \\
& 16 & 16 & 16 & 16 & \\
\hline A & 57,4 & 126, & 157, & 135, & 125,6 \\
1.1 & 17 & 366 & 897 & 720 & 00 \\
A & 50,2 & 86,1 & 136, & 143, & 104,0 \\
1.2 & 40 & 26 & 366 & 543 & 69 \\
B & 14,3 & 43,0 & 100, & 122, & 69,97 \\
2.1 & 54 & 63 & 480 & 011 & 7 \\
B & 28,7 & 86,1 & 71.7 & 107, & 73,56 \\
2.2 & 09 & 26 & 71 & 657 & 6 \\
C & 46,6 & 78,9 & 122, & 107, & 88,81 \\
3.1 & 51 & 49 & 011 & 657 & 7 \\
C & 43,0 & 78,9 & 114, & 122, & 89,71 \\
3.2 & 63 & 49 & 834 & 011 & 4 \\
\hline
\end{tabular}

\subsubsection{Sediment Grain Size}

The result of sediment data processing showed sediment type in the research location there are 3 types, namely Sandy Silt, Clayey Silt and Sandy Clayey Silt.

Table 3. Grain size and sediment types

\begin{tabular}{lclll}
\hline Station & $\begin{array}{c}\text { Sand } \\
\%\end{array}$ & $\begin{array}{l}\text { Silt } \\
\%\end{array}$ & $\begin{array}{l}\text { Clay } \\
\%\end{array}$ & $\begin{array}{l}\text { Sediment } \\
\text { Type }\end{array}$ \\
\hline A & 8,646 & 80,236 & 11,119 & Clayey Silt \\
B & 17,272 & 75,208 & 7,520 & Sandy Slit \\
C & 10,663 & 78,188 & 11,149 & Sandy \\
Clayey Silt
\end{tabular}

\subsubsection{Mangrove Vegetation}

The result of the research shows that there are 4 mangrove species (Table 4) from 16 species of mangrove in the coastal area of Pasar Banggi (Tomlinson, 1994) and categorized as the major component.

Table 4. Type of mangroves found in measurement transects

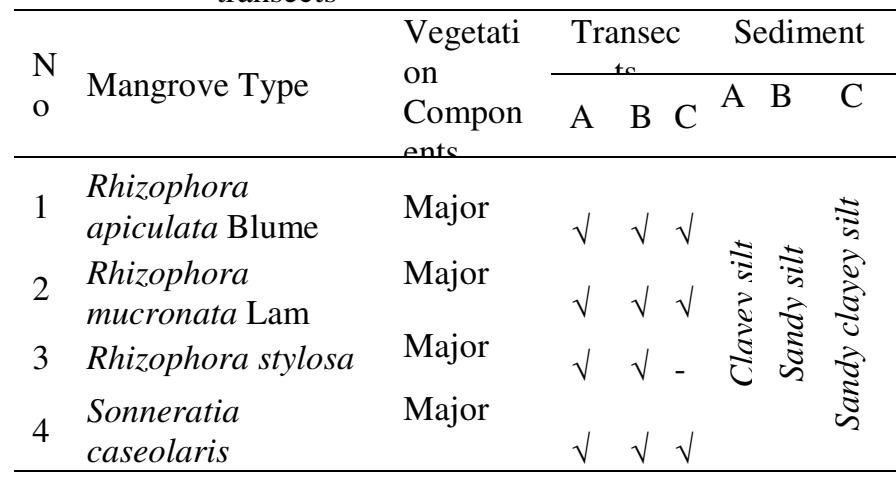

Fig 2 presents the mangrove density values in all categories at each research station. The highest tree density at station B with $\mathrm{K}=3400 \mathrm{ind} / \mathrm{ha}$, medium density at station $\mathrm{C}$ with $\mathrm{K}=2667 \mathrm{ind} / \mathrm{ha}$, and lowest density at station A with $\mathrm{K}=2133 \mathrm{ind} / \mathrm{ha}$. While the highest sapling density at station 
$\mathrm{B}$ with $\mathrm{K}=2533$ ind/ha, the medium density at station $\mathrm{C}$ with $\mathrm{K}=1600 \mathrm{ind} / \mathrm{ha}$, and lowest density at station A with $\mathrm{K}=1333 \mathrm{ind} / \mathrm{ha}$. The highest seedling density at station $\mathrm{B}$ with $\mathrm{K}=310000 \mathrm{ind} / \mathrm{ha}$, the medium density at station $\mathrm{C}$ with $\mathrm{K}=260000 \mathrm{ind} / \mathrm{ha}$, and lowest density at station A with $\mathrm{K}=170000$ ind $/$ ha.
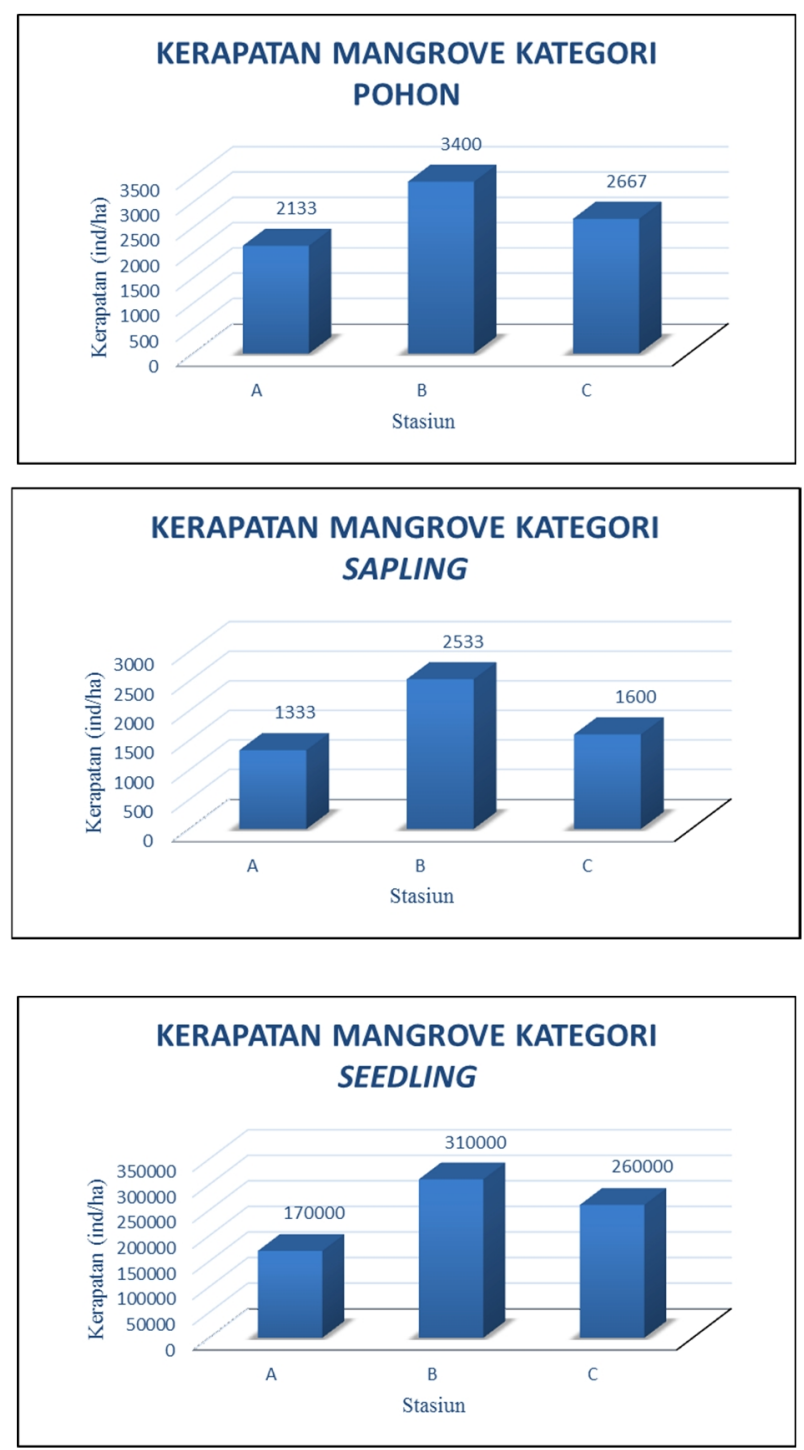

Fig 2. Mangrove density in all categories at each research station

\subsubsection{Physicochemical Parameter of Waters}

The acquisition of physicochemical data of waters in all study sites is not much different at each station. However, the data obtained are categorized well enough for mangrove environmental conditions in accordance with the Quality Standard in the Ministry of Environment Decree No. 51 of 2004.

\subsubsection{Tidal}

The value of formzahl obtained in November 2016 and December 2016 were 0.954 and 1.081 , respectively, so that the categorized tidal type in the waters of Pasar Banggi Beach of Rembang Regency mixed tended prevailing semidiurnal.

Table 5. Elevation of water level

\begin{tabular}{ccc}
\hline Information & $\begin{array}{c}\text { November } \\
2016\end{array}$ & $\begin{array}{c}\text { December } \\
2016\end{array}$ \\
\cline { 2 - 3 } & $\begin{array}{c}\text { Elevation } \\
(\mathrm{cm})\end{array}$ & $\begin{array}{c}\text { Elevation } \\
(\mathrm{cm})\end{array}$ \\
\hline HHWL & 125 & 105 \\
LLWL & 37 & 15 \\
MSL & 81 & 60 \\
HWL & 103 & 82 \\
LWL & 58 & 38 \\
\hline
\end{tabular}

\subsubsection{Statistic test}

Data analysis has been done that the rate of sedimentation and mangrove density has a perfect negative relationship with the higher rate of sedimentation, the lower the mangrove density, and the lower the sedimentation rate, the higher the mangrove density.

Table 6. Plot of sedimentation rate correlation data on mangrove density

\begin{tabular}{|c|c|c|c|}
\hline \multicolumn{4}{|c|}{ Correlations } \\
\hline & & $\begin{array}{l}\text { Mangrov } \\
\text { e Density }\end{array}$ & $\begin{array}{c}\text { Sedimentatio } \\
\text { n Rate }\end{array}$ \\
\hline \multirow{3}{*}{$\begin{array}{c}\text { Sedimentatio } \\
\text { n Rate }\end{array}$} & $\begin{array}{l}\text { Pearson } \\
\text { correlatio }\end{array}$ & 1 &,- 999 \\
\hline & $\begin{array}{l}\mathrm{n} \\
\text { Sig. } \\
\text { tailed) }\end{array}$ & & ,028 \\
\hline & $\mathrm{N}$ & 3 & 3 \\
\hline \multirow{3}{*}{$\begin{array}{l}\text { Mangrove } \\
\text { Density }\end{array}$} & $\begin{array}{l}\text { Pearson } \\
\text { correlatio }\end{array}$ &,- 999 & 1 \\
\hline & $\begin{array}{l}\mathrm{n} \\
\text { Sig. } \\
\text { tailed) }\end{array}$ & ,028 & \\
\hline & $\mathrm{N}$ & 3 & 3 \\
\hline
\end{tabular}

\subsection{Discussion}

The 4 mangrove species found are categorized as major components, i.e. groups or vegetations that form pure stands which form specific physiology morphology and a mechanism to maintain its survival and this group or vegetation never join the land plant group. Mangroves at the study sites are included in good stands because they have a mangrove vegetation density of tree level $>1500 \mathrm{ind} / \mathrm{ha}$ according to Ministry of Environment Decree No. 201 of 2004 to determine the extent of mangrove damage. The mangrove vegetation density value for the tree level obtained is smaller when compared to the mangrove density value for seedling rates ranging from 170000 - 310000 $\mathrm{ind} / \mathrm{ha}$. This is because the rehabilitation of the mangrove area of Pasar Banggi is high enough to make mangrove seedling level (seedlings) more than the tree level.

Physicochemical characteristic of mangrove ecosystem environment is very important for mangrove growth. Temperature is an important factor for mangrove growth in 
physiological processes such as photosynthesis and respiration. The lowest temperature value is $28,5^{\circ} \mathrm{C}$ while the highest temperature value is $31^{\circ} \mathrm{C}$. The low and high temperature values obtained are suspected due to weather factors at the time of data collection. Low temperatures are due to the early morning shooting so the sun has not yet illuminated the water bodies, while the high temperatures are due to daytime retrieval where the sun is already illuminating the water bodies. According to Aksornkoae (1993) in Petra et al., [3] salinity is a crucial environmental factor determining the development of mangrove forests, especially for growth rate, endurance, and zonation of mangrove species. The lowest salinity value is $28.5 \mathrm{ppt}$ while the highest salinity value is $31 \mathrm{ppt}$. The difference in the value obtained is due to the location of the research is the waters through which open sea water mass so that the current movement affects the salinity value obtained. In line with the statement of Nontji (2002) [4], factors affecting salinity fluctuations are water circulation patterns, availability and supply of fresh water, evaporation, rainfall, and river flows. The value of the acidity degree obtained is fairly constant no change, nevertheless back to the above statement that the value of the physicochemical parameter is quite ideal according to the Quality Standard of the Ministry of Environment Decree No. 51 of 2004 so that no matter the value obtained is constant.

Tidal types on Pasar Banggi beaches correspond to formzahl numbers obtained according to Ongkosono and Suyarso (1986) [5] , $0.25<\mathrm{F} \leq 1.5$ so as to be categorized mixed tide prevailing semidiurnal. The variation in the current velocity value every week at the observation site will affect the sedimentation rate. The dominating current at the observation site is the tidal generated currents that play a role in the spread of coastal sediments and abrasion. Based on the calculation, the current velocity value ranges from $0.0055-0.0362 \mathrm{~m} / \mathrm{s}$ with the east dominant current direction. Differences in the value of current velocity generated at the study site as a result of mangrove density. According to Roza et al [2] the mangrove species Rhizophora sp is a pioneer plant (major) that physically has stilt roots that serves as a damper of incoming water velocities that decreases the velocity of water flow. The density of this flow further weakens, resulting in the deposition of particles deposition to the bottom of the waters in the area of mangrove. This will also affect the value of the sedimentation rate obtained, the greater the velocity of the current the smaller the sediment is deposited and the smaller the feeding rate the larger the sediment is deposited. The highest average sedimentation rate on station A was $291,479 \mathrm{gr} / \mathrm{cm}^{2} /$ day with the lowest average current velocity of $0.011 \mathrm{~m} / \mathrm{s}$ and the lowest mangrove density was 57822 ind/ha. The average value of the lowest sedimentation rate at station B was $171,095 \mathrm{gr} / \mathrm{cm}^{2} /$ day with the highest average current velocity of $0.0178 \mathrm{~m} / \mathrm{s}$ and the highest mangrove density was $105311 \mathrm{ind} / \mathrm{ha}$. The mean value of medium sedimentation rate at station $\mathrm{C}$ is 219,461 $\mathrm{gr} / \mathrm{cm}^{2} /$ day with average velocity of $0-1133 \mathrm{~m} / \mathrm{s}$ and medium mangrove density of $88089 \mathrm{ind} / \mathrm{ha}$.

The weak current velocity (slow) has small sediment transportability. Koesoemadinata (1985)[6] explains that sediment transport or transport is influenced by current velocity and grain size. The larger the grain size, the greater the current velocity required to transport it. This is in accordance with the statement of Koesoemadinata (1985)[6] that station A with a small current velocity has a grain size of sediment in the form of clayey silt. Station B with a large current velocity has a grain size of sediment in the form of sandy silt. Station C with medium current speed has a grain size of sediment in the form of sandy clayey silt. The relationship between the two is done by statistical test with Pearson correlation test. Based on the test results in accordance with the criteria of the test (hypothesis), the sedimentation rate has a relationship (strong) with mangrove density, with a significant value of 0.028 . Based on the table, the value of the relationship between the two of -0.999 or rounded to -1 , is defined as a perfect negative relationship (opposite). The value of the relationship corresponds to the correlation value obtained by Petra et al., (2012) where the correlation coefficient value is -1 (negative 1). This negative value only determines the direction only by having a very strong relationship or 0.999 . The negative value means that the higher the sedimentation rate, the lower the mangrove density and the lower the sedimentation rate, the higher the mangrove density. This is because the mangrove density affects the sedimentation rate.

\section{CONCLUSIONS}

Based on the results of research that have been done in the area of Mangrove in Pasar Banggi obtained, the station A has the highest average sedimentation rate of 291,479 $\mathrm{gr} / \mathrm{cm}^{2} /$ day with the lowest average mangrove density of 57822 ind/ha. Station B has the lowest average sedimentation rate of $171,095 \mathrm{gr} / \mathrm{cm}^{2} /$ day with the highest average mangrove density of 105311 ind/ha. Station C which has an average sedimentation rate of 219.461 $\mathrm{gr} / \mathrm{cm}^{2} /$ day with average mangrove density of $88089 \mathrm{ind} / \mathrm{ha}$. The relationship between mangrove density and sedimentation rate at Pasar Banggi Beach shows negative correlation value $(-1)$, which means that the higher sediment is deposited, the lower the mangrove density and the lower the sediment is deposited, the higher the mangrove density.

\section{REFERENCES}

1. Maulana, E.,Wulan, R.T., Wahyuningsih, S.D., Mahendra, I.W.W.Y., dan Siswanti, E. 2016. Strategi Pengurangan Risiko Abrasi Di Pesisir Kabupaten Rembang, Jawa Tengah. Dalam: Prosiding Seminar Nasional Upaya Pengurangan Risiko Bencana Terkait Perubahan Iklim di Hotel Syariah Solo Tanggal 4 Juni 2016. Solo, Jawa Tengah.

2. Roza, Y.S. 2016. Kontribusi Mangrove Dalam Memerangkap Sedimen Di Wilayah Pesisir Kota Dumai Riau. [Thesis]. Program Pascasarjana, Institut Pertanian Bogor, Bogor, 42 hlm.

3. Petra, J.L., Sastrawibawa, S., dan Riyantini, I. 2012. Pengaruh Kerapatan Mangrove Terhadap Laju Sedimen Transpor Di Pantai Karangsong Kabupaten Indramayu. Jurnal Perikanan dan Kelautan., 3(3): 329337.

4. Nontji A. 1985. Laut Nusantara. Djambatan Pr. Jakarta. 
5. Ongkosongo, O. S. R. dan Suyarso. 1989. Pasang Surut. Pusat Penelitian dan Pengembangan Oseanologi (P3O) LIPI. Jakarta.

6. Koesoemadinata, R. P. 1985. Prinsip - Prinsip Sedimentasi. Jurusan Teknik Geologi, Institut Teknologi Bandung. Bandung.

7. Buchanan, $\mathrm{K}$ and Holme Mc Intyre. 1984. An Introduction to Coastal. Harper and Row Publisher. New York.
8. Pettijohn, F.J. 1975. Sedimentary Rock. Harper and Row Publisher. New York.

9. Sugiyono. 2009. Metode Penelitian Kuantitatif Kualitatif R\&D. Alfabeta. Bandung.

10. Supriharyono. 1990. Hubungan Tingkat Sedimentasi dengan Hewan Makrobentos di Perairan Muara Sungai Moro Demak Kab. Dati II Jepara. Lembaga Penelitian Universitas Diponegoro. Semarang. $59 \mathrm{hlm}$. 